\title{
Research into practice: CLIL in South America
}

\author{
Darío Luis Banegas (D) \\ School of Education, University of Strathclyde, Scotland, UK \\ Email: dario.banegas@strath.ac.uk
}

\begin{abstract}
This paper discusses three relationships between content and language integrated learning (CLIL) research and practice in the context of South America. The first relationship focuses on research with successful results in the areas of language learning motivation and intercultural communicative competence and citizenship. The second relationship discusses research which has yielded mixed results to support language learning and cognitive development. The last relationship suggests what areas deserve special attention to offer further support to teachers involved in CLIL provision. The following areas are addressed: teacher-made CLIL materials, language and content gains, L1-L2 (first language, second language) curriculum design, and inclusion. In conclusion, I assert that CLIL in South America can be invigorated if researchers and educators carry out research, preferably in collaboration, that recognises, maximises and improves CLIL in practice. I also suggest that the CLIL community in South America may engage in creating CLIL models and conceptual frameworks that respond to the particularities of their settings with the aim of making CLIL context-responsive and sustainable.
\end{abstract}

\section{Introduction}

The integration of content and language is a well-established pedagogical view in L2 education (see Glyn Lewis, 1976), which has been realised through different approaches that share the position that L2 learning improves when it is contextualised in the learners' L1 curriculum (Leaver \& Stryker, 1989; Lyster, 2007; Valeo, 2013; Lightbown, 2014). According to Lightbown and Spada (2019), the integration of language teaching and academic subjects (e.g., Geography) adds more time to L2 learning without subtracting time from meaningful content learning.

One such approach is CLIL. The term was originally developed in Europe in the 1990s in response to the agreed policy of supporting EU citizens in operating in their L1 plus two other EU languages (European Commission, 1995; Marsh \& Nikula, 1998; Marsh \& Langé, 1999; Eurydice, 2006; Marsh \& Wolff, 2007). Since its inception, the following dominant underpinnings have served as the conceptual basis for CLIL practice: sociocultural theory of learning (Coyle, Hood, \& Marsh, 2010; Bower, Coyle, Cross, \& Chambers, 2020), systemic functional linguistics (Llinares, Morton, \& Whittaker, 2012; Llinares \& Morton, 2017) (connected to classroom discourse, interaction, and genre theory), cognitive (lower-order and higher-order thinking skills) processes (Coyle et al., 2010), and authenticity of content, input, and tasks (Pinner, 2013).

As an umbrella term for different models of bilingual education (Dalton-Puffer, Llinares, Lorenzo, \& Nikula, 2014), CLIL is often defined as a pedagogical approach in which 'a foreign language is used as a tool in the learning of a non-language subject in which both language and the subject have a joint role' (Marsh, 2002, p. 58). This definition may indicate that CLIL's most logical context is, for example, a Science or History classroom (e.g., Gallardo del Puerto, Basterrechea, \& Martínez Adrián, 2019). Thus, CLIL focuses on content learning through an L2, which is learnt in an integrated manner. On the issue of integration, Nikula, Dafouz, Moore, and Smit (2016) wonder about the extent to which L2 learning is successfully scaffolded and achieved in the mainstream classroom across different

(C) The Author(s) 2021. Published by Cambridge University Press. This is an Open Access article, distributed under the terms of the Creative Commons Attribution licence (http://creativecommons.org/licenses/by/4.0/), which permits unrestricted re-use, distribution, and reproduction in any medium, provided the original work is properly cited. 
settings where learners may exhibit heterogeneous levels of L2 language proficiency. This concern raises the issue of whether CLIL may be implemented with all learners, regardless of their L2 proficiency. On this complex matter, both in European (e.g., Ball, Kelly, \& Clegg, 2015) and South American experiences (e.g., Rodriguez Bonces, 2011), CLIL teachers note that CLIL may yield positive results with learners who already hold, through previous and/or additional L2 exposure, high levels of English as curricular content cannot be simplified at the expense of language support.

However, since its inception and continuous developments in research alongside implementation (e.g., Coyle, 2007; Goris, Denessen, \& Verhoeven, 2019), CLIL has attracted the attention of researchers and educators around the world, thus burgeoning in diverse countries and educational systems (e.g., Pérez-Cañado, 2012; Tsuchiya \& Pérez Murillo, 2019; Bower et al., 2020; Hemmi \& Banegas, 2021). CLIL expansion across different contexts has brought about a wide range of CLIL models, from school subjects entirely delivered through an L2 to project work at the end of a term or school year. Hence, current CLIL practices can be understood along a continuum (Cenoz, 2015; Airey, 2016) with two ends: (1) a focus on content learning (e.g., Science taught by a Science teacher in Austria through the medium of English), and (2) a focus on L2 learning (e.g., an English as a foreign language (EFL) teacher in Argentina contextualising the teaching of passive voice through local history).

One of the geographical contexts in which CLIL has disembarked is South America. According to a review of CLIL in South America between 2008 and 2018, Banegas, Poole, and Corrales (2020), 2008 could be considered the year which witnessed the first outputs (e.g., Fernández, 2008) drawing on CLIL practices in the region. Since then, regional and, to a significant lesser extent, international outlets have included empirical and descriptive articles of CLIL in practice conducted in South America. Consequently, there is a growing body of publications which testify how CLIL has been implemented by practitioners in different South American educational settings (for a review, see Banegas, Poole, \& Corrales, 2020). Despite such promising growth, there is a paucity of studies which discuss the extent to which CLIL research confidently informs CLIL practice in South America.

Drawing on my own experience as an L2 (English) practitioner, teacher educator in Argentina and visiting lecturer in South America, the purpose of this paper is to discuss the relationship between CLIL research and practice in South America. I circumscribe my discussion to three relationships: (a) where research has yielded successful results, (b) where research has provided mixed results, and (c) what research is needed to support language as well as content teachers in the classroom. For each relationship I concentrate on specific areas which South American teacher-researchers and practitioners have highlighted in practice.

The discussion provided below should be approached with caution for two main reasons. First, the areas selected are inevitably connected to my own areas of pedagogical and research interest and what has been published and made publicly available in the context of South America. Second, the in-practice comments and examples I offer come from my own experience in implementing CLIL in secondary and higher education as well as supporting teachers through continuing professional development initiatives which include classroom observation and peer lesson planning and delivery. At the risk of sounding anecdotal, these experiences may illustrate unpublished CLIL pedagogical contours.

\section{Research with successful results}

Research in the areas of language learning motivation and intercultural communicative competence and citizenship seem to find traction in South American CLIL. Below, I discuss publications and accounts which illustrate both areas.

\subsection{Language learning motivation}

Motivation is often viewed as one of the most determining factors in language learning (Ushioda, 2016; Lamb, Csizér, Henry, \& Ryan, 2019). CLIL research is confident in demonstrating that CLIL 
models may enhance L2, usually English, learning motivation in settings where English is a mandatory subject in the school curriculum (Lasagabaster, Doiz, \& Sierra, 2014; Lasagabaster, 2019). Albeit inconclusive, findings show that CLIL enhances learners' motivation to learn English (Banegas, 2013) and content (Lasagabaster, 2011; Doiz, Lasagabaster, \& Sierra, 2014; Lasagabaster \& Doiz, 2017). The rationale underpinning these findings is that CLIL contributes to motivation enhancement as the content, materials, tasks, and L2 communication (Fazzi \& Lasagabaster, 2020) are authentic and connected to learners' academic interests and the L1 curriculum. According to Pinner (2013, 2019), learners are drawn into a CLIL classroom as they realise that the subject matter has not been modified to match their L2 proficiency. In addition, learners become aware that they can resort to prior knowledge acquired in their L1 or mainstream language of schooling and engage in transferring skills for learning new content and new language in tandem.

In South America, three recent studies carried out by teacher-researchers attest to the relationship between CLIL, motivation, and authenticity. For example, in Colombia, Keogh (2017) deployed the use of WhatsApp as an extension of the higher education classroom to discuss topics related to international relations. Learners' self-reported reflections showed that their motivation increased as they engaged in discussion (an authentic task) through an authentic means (WhatsApp) to discuss academic content in English. In an action-research based study, Banegas (2018) implemented a CLIL approach within an English for specific purposes course to enhance the motivation of a group of Geography student-teachers at an Argentinian teacher education institution. Findings show that the student-teachers not only displayed an increase in motivation but also in English language learning as they found the authentic sources of input (geography coursebooks and journal articles) inherently relevant to the subject-matter of their programme. Last, Banegas (2018) and Lauze (2020) implemented language-driven CLIL with a group of secondary school learners to incorporate comprehensive sexuality education topics as required by Argentinian laws. According to the group interviews, the learners considered the experience motivating and context-sensitive as the topics were authentic and in alignment with the L1 curriculum. Furthermore, they explained that having to design posters and leaflets for the school as part of the pedagogical experience motivated them to participate actively in class.

As in other settings, South American EFL teachers often plan CLIL lessons based on authentic content drawn from the L1 curriculum. For example, in a study conducted in a Colombian university, a group of EFL teachers reported designing their CLIL lessons drawing on the mandatory modules present in their students' undergraduate programmes (Banegas, Corrales, \& Poole, 2020). In a secondary school in Argentina, a group of L2 (English and French) teachers organised a series of meetings with the L1 teachers and agreed on a series of arts-related topics to engage the learners in project work (Castellani, Dabove, \& Colucci, 2009). When learners are provided with authentic sources of input, content is usually supported through graphic organisers to orient learners towards key concepts and terms (e.g. Anderson, Mora González, \& Cuesta Medina, 2018).

In other cases, CLIL provision is operationalised by means of teacher-modified materials to match learners' needs and L2 proficiency. Materials modification often follows the procedures outlined in Lorenzo (2008): expanding a text by adding examples or definitions, simplifying a text through paraphrasing, or including bullet points and visuals to expand textual features. In addition, teachers may include authentic activities such as debates, cross-curricular projects carried out in both Spanish and English, or video-based presentations. For example, in a content-driven CLIL Science classroom in Colombia, Garzón-Díaz (2018) incorporated technology-enhanced collaborative projects which allowed the learners to produce their own videos about environmental science. The learners reported that the use of a wide range of sources of input and the nature of the tasks boosted their interest in English language learning.

Whether CLIL is based on authentic or modified materials, different studies confirm teachers' use of translanguaging as a strategy to support learners. Translanguaging may be minimally defined as a speaker's use of all their linguistic tools and languages as part of a space to communicate and learn (García \& Lin, 2017). Nikula and Moore (2019) report that the deliberate alternation of languages in the CLIL classroom serves the purpose of orienting learning and supporting interaction. 
Whereas L2 remains prominent, the L1 is not neglected as a tool for learning. In a study conducted with secondary school learners in Colombia, Garzón-Díaz (in press) shows that allowing learners to engaging in translanguaging (L1 Spanish and L2 English) when working on mini-research projects allowed them to remain motivated and engaged with the tasks set as they noted that being able to utilise both languages supported their confidence in communicating their findings in class. In a similar vein but with adult learners, Anderson (2011) found that translanguaging not only enhanced learner motivation but also their cognitive academic language proficiency (CALP).

\subsection{Intercultural communicative competence and citizenship}

Culture, understood as a parameter in CLIL practice (Coyle et al., 2010), is systematically featured in CLIL research and practice in South America. In such studies, culture is associated with the notions of intercultural communicative competence, and more recently, intercultural citizenship (Porto, 2018). According to the Council of Europe (2016, p. 168), intercultural communicative competence can be defined as 'the ability to use languages for the purposes of communication and to take part in intercultural interaction, where a person, viewed as a social agent has proficiency, of varying degrees, in several languages and experience of several cultures'. For example, Porto (2016) conducted a study with primary school learners in Argentina and Denmark. The learners worked on collaborative projects concerning the environment which involved the creation of posters and videos while engaging in English-medium intercultural interaction. The author explains that the projects combined 'foreignlanguage education and citizenship education' and integrated 'the pillar of intercultural communicative competence from foreign language education with the emphasis on civic action in the community from citizenship education' (p. 399). Porto (2016) concludes that the initiative allowed the learners to develop both national and transnational identifications around a topic that exceeds locality and temporality. With a focus on interculturality, the thrust in current CLIL research is that learners may develop a critical understanding of situated cultural practices at different levels of social and personal life. Such levels are not only developed in relation to others but also in relation to the learners themselves in their immediate context (Méndez García, 2012; Porto, 2018; Roiha \& Sommier, 2018).

CLIL implementation has also facilitated the inclusion of interculturality and citizenship in the L2 classroom based on topics which are often ignored or misrepresented in general English coursebooks. For example, in Argentina, Helver (2015) carried out an action research project through which she developed a series of language-driven CLIL lessons with her teenage learners about the revitalisation of aboriginal languages in Argentinian territory. In this experience, interculturality pedagogically channelled through CLIL allowed the teacher to explore local cultures. Drawing on the learners' comments and her own observations, the author concludes that they developed awareness of the diversity of languages and social practices across Argentina which are usually invisibilised or marginalised in the school curriculum.

Alongside the aforementioned experiences, teachers have engaged their EFL learners in lessons in which they discuss plurilingualism in their own contexts and reflect on the importance of intercultural awareness and linguistic diversity to promote social justice among citizens. Such practices are illustrated in a study conducted by Rodas and Santillán (2018) in Ecuador. The authors describe the actions taken by a group of secondary school teachers to develop their own materials to cater for the particularities of their teaching context. The materials and lessons in which they were employed promoted the use of learners' linguistic repertoire, thus creating a space in which translanguaging enabled the learners to attain a firm grasp of intercultural citizenship. While the Ecuadorian experience places interculturality in a space where diversity and social justice operate as key constructs in educational dynamics, some South American authors have raised concerns about the operationalisation of interculturality and CLIL in other settings. For example, Pimentel Siqueira, Landau, and Albuquerque Paraná (2018) have warned that CLIL initiatives in Brazil, usually framed as foreign language bilingual education, include an intercultural orientation that may still perpetuate the use of a hegemonic language to understand the learners' own diverse cultural backgrounds. In Ecuador, a 
recent study has shown that teachers may have heterogeneous conceptions of interculturality, some of which may perpetuate stereotypical views of English-speaking 'culture' (Fernández-Agüero and Chancay-Cedeño, 2019). As a reaction to this concern, Megale and Coelho Liberali (2016) promote the concept of superdiversity in language education in Brazil to include, on the one hand, a plurilingual perspective in CLIL, and on the other, to challenge the practice of CLIL only for the elites in Brazil and elsewhere in the continent.

Framed in intercultural citizenship, the spread of a gender perspective in education to raise awareness of high femicide rates in South America has led L2 educators in Argentina (e.g., Banegas \& Lauze, 2020) and Chile (e.g., Acosta \& Yilorm, 2016) to design and implement lessons that may enable learners to reflect on identity, gender, diversity, and, above all, human rights, and dismantle dominant heteronormative and patriarchal discourses. With the same aim, CLIL and gender has become the main concern of continuing professional development opportunities. For example, Cossu, Brun, and Banegas (2021) describe a workshop in which teachers and student-teachers worked in groups to design lesson plans with content and language aims where the content was related to comprehensive sexual education. In this workshop, Coyle's (2007) 4Cs model (content, cognition, culture, and communication) was offered as a lesson organiser to ensure a holistic approach to the discussion of gender in the CLIL classroom. In the cases mentioned, CLIL and gender topics acted as a space for raising learner motivation while promoting knowledge about inclusive social practices through the medium of English. Through these initiatives, learners and teachers are empowered to use English as another means to address current issues that are present in society at large.

The studies reviewed in this section are located at the interface of CLIL, motivation, and intercultural communicative competence and intercultural citizenship and they found traction among teachers as discussed in Banegas, Poole, and Corrales (2020). This shift to including topics which are not usually found in L2 education is also the consequence of recent changes in language teacher preparation programmes and continuing professional development opportunities. As illustrated in recent studies in Argentina (Banegas \& del Pozo Beamud, 2020) and Chile (Barahona \& Benítez, 2020), language teacher education programmes in South America are moving beyond a focus on form and the acritical reproduction of hegemonic approaches and are slowly embracing and developing culturally-situated language learning pedagogies.

\section{Research with mixed results}

According to the publications available and my own experiences, CLIL research, mostly carried out by teacher-researchers, has also yielded mixed results in terms of positive impact on learners' language and cognitive development.

\subsection{Supporting language learning}

For the integration of language teaching and content, Lightbown and Spada (2019) underscore that learners need to receive quality L2 linguistic support to cope with school demands and CALP. According to the CLIL literature, language learning can be supported by means of what has been called the language triptych (Coyle et al., 2010; Pérez Cañado, 2016; Pavón Vázquez, 2018). The language triptych entails providing learners with systematic and organic opportunities for learning subject-specific terminology (the language of learning), general academic language needed for successful task completion (the language for learning), and spontaneous language demands as a result of classroom engagement (the language through learning). CLIL research argues for the explicit and implicit teaching of language structures and lexis that enable learners to understand and co-construct knowledge in interaction with others in and beyond the classroom. While the language triptych seems to offer an attractive pedagogical 'solution' to communication in CLIL, there is a lack of studies which report the language triptych in practice and its effectiveness.

Studies show that teachers may struggle with providing organic language support in their daily practices. In a case study-based investigation carried out with 11-12-year-olds in a Colombian 
bilingual school, Mariño Avila (2014) observed that the CLIL teachers (content teachers who were proficient in English) failed to provide opportunities for L2 learning. While the learners communicated in English in class to complete maths and science activities with varying degrees of success, the teachers missed the chance to direct learners' attention to language-focused tasks. As a consequence, the learners did not exhibit significant improvement in accuracy or subject-specific terms.

Insufficient support for learners' CALP development may be a consequence of teachers' struggle with differentiating between subject-specific and general academic vocabulary. For example, Torres-Rincón and Cuesta-Medina (2019) conducted a qualitative study with six EFL teachers in different Colombian cities. They found that the teachers showed a tendency to equate CLIL to providing vocabulary from the L1 subjects. Subject-specific terms, i.e. the language of learning, were not embedded in practices which failed to promote learning beyond lexical items. The sole focus on learning lexical items may be the result of EFL teachers' inevitable lack of subject-matter preparation in, for example, Science. However, it would be reductive and of little practicality to address this issue by asking EFL teachers to train as, for example, Science teachers. What emerges here is whether it is fair to expect quality CLIL provision by increasing the pressure on EFL teachers' workload and duties without professional support or improvement of working conditions.

Possibly due to the slow, yet steady, transition from form-focused instruction to meaning-focused instruction in language teacher education programmes and practice, teachers also may find it problematic to determine the language for learning. As mentioned above, the language for learning refers to the language learners need to complete a task. Grammatical structures and cohesive devices may be considered constitutive elements of language for learning. However, grammar instruction needs to be accommodated to match the academic content.

One study may illustrate the minimal effect of maintaining traditional grammar instruction in a CLIL environment. In a quasi-experiment study carried out with higher education learners at a school of tourism in Ecuador, Vega and Moscoso (2019) sought to find whether providing direct grammar instruction to a CLIL class would lead to English language improvement. To this effect, learners were divided into two groups: a CLIL group and non-CLIL group. While content on tourism was prioritised in the former, the latter received English for specific purposes (ESP) instruction with a focus on vocabulary and functional language. Both groups received direct grammar instruction drawing on the same English for Tourism coursebook the authors had set for the programme. From tests and questionnaires, findings showed that there were no significant differences in term of language proficiency between the CLIL and the non-CLIL group.

In other cases, the novelty of the approach may direct teachers to disregard L2 learning altogether and concentrate on content instead. For example, in southern Chile, I visited a primary school class where, on the topic of water conservation, the learners had to compare and contrast different photographs. The learners struggled with the task because they did not have the language items (e.g., comparative adjectives, linking words to show contrast) to express the discourse functions of comparing and contrasting.

Lastly, it should be mentioned that despite the CLIL literature favouring language awareness raising activities to support language learning (e.g., Ruiz de Zarobe, 2015), South America has not yet delivered studies which examine language awareness and CLIL provision. Only one publication (Cendoya \& Di Bin, 2010), which describes a pedagogical experience, has explored language awareness in connection to genre-based pedagogy to aid primary school learners in the completion of writing tasks. Drawing on the analysis of the learners' compositions, the authors conclude that language awareness tasks at the levels of clause and text succeed in supporting learners' writing development.

\subsection{Supporting cognitive development}

In CLIL, thinking processes are described following Bloom's revised taxonomy of lower-order and higher-order thinking skills (LOTS and HOTS) (Coyle et al., 2010; Uribe-Enciso, Uribe-Enciso, \& Vargas-Daza, 2017). Thinking skills can also be linked to activating learners' prior knowledge to 
understand new knowledge (Alonso-Belmonte \& Fernández-Agüero, 2018). Coyle et al. (2010) suggest a CLIL matrix to support teachers in balancing linguistic and cognitive demands. Equipping learners with thinking skills and strategies in tandem with the language needed to perform those skills enables them to deal with the demands of L2-medium instruction.

While CLIL practice set in South America underlines the paramount importance of incorporating thinking skills in relation to critical thinking and citizenship, publications do not often describe how LOTS and HOTS are developed in relation to the type of language needed for meaningful learning. For example, Finardi, Silveira, Lima, and Mendes (2016) describe an English for academic purposes course which combines CLIL with a massive open online course in a Brazilian Navy boarding school. The authors put forward a set of activities sequenced from less to more demanding cognitive load (e.g., matching terms and definition, analysing charts, discussing questions) and state that such activities promote critical thinking. Nevertheless, it is not apparent how the cognitive processes underlying such activities are calibrated in relation to both language input and language output.

One study, however, attempts to discuss the dynamics between linguistic demands and cognitive development. Argudo, Abad, Fajardo-Dack, and Cabrera (2018) employed a language test and a survey to (a) measure the English language proficiency (ELP) of a group of $121 \mathrm{EFL}$ student-teachers at a university in Ecuador and (b) understand their perceptions of language, content, and cognitive development in their teacher education programme. The findings showed that half of the participants had an A1-A2 level (CEFR, Common European Framework of Reference for Languages), which was insufficient to understand and, consequently, evaluate input provided in the programme. The study not only attests to the relationship between language and cognition in CLIL, but it also illustrates how lecturers struggle with offering support and input that balances linguistic and cognitive demands. On the other hand, in times of the expansion of CLIL and English-medium instruction in higher education (Macaro, Curle, Pun, An, \& Dearden, 2018), the study unveils the problematic distance between ELP admission requirements and lecturers' expectations and module requirements within the same institution.

This section may be regarded as biased as it highlights that where CLIL research has not yielded successful outcomes, the discrepancy between CLIL research findings and their CLIL implementation is the result of insufficient teacher support or the need to critically examine published CLIL findings. However, the identification of mixed results may signal that a critical review of published CLIL research findings is imperative (see Paran, 2013; Bruton, 2019).

\section{What CLIL research is still needed?}

While the sections above have discussed important areas which have gained traction among CLIL researchers and practitioners in South America, recent publications have highlighted four key areas that deserve attention: (1) teachers as CLIL materials developers, (2) language and content gains, (3) synergy between L1-L2 curriculum design, and (4) inclusion.

\subsection{Teacher-made CLIL materials in action}

CLIL authors (e.g., Ball et al., 2015; Pimentel Siqueira et al., 2018) agree that one of the obstacles for successful CLIL provision, whatever the model, is the lack of appropriate materials as scaffolding tools (Mahan, 2020). Since CLIL entails connections between the L1 and the L2 curricula, global coursebooks could not cater for every school's needs. Hence, CLIL authors have suggested principles for teacher-made CLIL materials (e.g., Mehisto, 2012; Banegas, 2017; Ball, 2018). The CLIL literature on materials has also displayed reflective accounts of materials developed by content teachers (Moore \& Lorenzo, 2015) as well as language teachers (Banegas, 2016; Zhyrun, 2016) for different CLIL models and settings.

Although the authors mentioned above suggest principles or describe materials developed by teachers to suit the needs of their own contexts, research on empowering and supporting teachers in CLIL 
materials development needs to receive further attention. For example, in two studies (McDougald, 2015; McDougald \& Pissarello, 2020) carried out with Colombian teachers, it has been found that while teachers recognise the benefits that CLIL entails in learners' development of language skills and subject knowledge, they underscore the need for specialised training particularly in the areas of materials development and lesson planning. In this regard, empirical studies are needed to understand the distance, tensions, affordances, and opportunities that emerge when teachers are supported in CLIL materials development and their subsequent implementation. CLIL research on teacher-made CLIL materials can shed light on what adaptations are needed. It can also inform the extent to which the CLIL models, principles, and frameworks found in the literature can shape and be shaped by practice not only in and for South America but also in other settings. Such a niche may in turn become a professional development opportunity for teachers to engage in teacher research.

\subsection{Language and content gains}

In a review of CLIL research carried out in Europe, Goris et al. (2019) conclude that, regardless of whether the studies were large or small scale, there is evidence of L2 gains. In South America, a few studies indicate that learners display improvement in terms of language development and academic content. For example, an action research study carried out with university students in Chile (De la Barra, Veloso, \& Maluenda, 2018) shows that developing learners' linguistic awareness can aid their improvement of oral competences, which in turn, has a positive impact on content learning. In Peru, Amado Valdivia (2012) designed a 4C-based course for teenagers and adults and reported that the learners experienced both language and content gains. Likewise, Anderson (2011) explored adult learners' CALP development in higher education courses.

Although CLIL research on linguistic and content gains is mushrooming, we need sophisticated and accurate accounts that describe and explain what language systems or specific linguistic items are boosted or hindered by CLIL practice. In fact, there is a need for sharper research studies with instruments that can measure, for example, specific lexical gains, language competences, or what areas of academic content are learnt through an L2. Findings from such studies will contribute to calibrating teachers' practices in supporting learning and teaching materials.

\subsection{L1-L2 curriculum design}

The fundamental principle of CLIL is the integration of learning school content and L2. Such a dual goal has brought about the CLIL continuum mentioned in Section 1. While authors discuss the rhetoric, approaches, and pedagogies behind a so-called integrated curriculum (e.g., Casal Madinabeitia, 2007; van Kampen, Meirink, Admiraal, \& Berry, 2017), CLIL research on curriculum development from a macro-perspective is much needed both in South America and elsewhere. This research might be particularly relevant in settings where CLIL is adopted as an educational approach. In such contexts, it is of paramount importance for epistemological, pedagogical, and logistic reasons that the school curriculum is designed as an integrated matrix from its inception. Differently put, the integrated curriculum is not the sum of the L1 curriculum and the L2 curriculum; it is an interconnected, holistic, and bilingual conception of education.

In contexts where teachers operate under two curricula (L1 and L2), effort should be made to understand, examine, and support synergies between both curricula, with the aim of providing learners with an educational experience that goes beyond specific subjects and languages. In this regard, project work and inquiry-based learning (Amaral, Garrison, \& Klentschy, 2002; Leat, 2017) may help envisage the school curriculum as a space for exploring translanguaging and maximising the potential role of the language of schooling (learners' L1 in most cases) for CLIL success (Lin, 2015). Given the variety of CLIL models and practices found in South America, educators can contribute to creating a powerhouse at the nexus of teaching-informed research and research-informed and context-sensitive practices. 


\subsection{Inclusion}

In Section 1 reference was made to whether CLIL could be beneficial to learners regardless of their L2 proficiency. Ball et al. (2015) have hinted that CLIL is not for all since one criterion for CLIL success is learner academic L2 ability so that teachers and learners can maintain acceptable levels of subject knowledge. Nevertheless, the authors acknowledge that it may be possible to 'run a good CLIL programme starting with learners with low or even zero L2 ability' (p. 12). In South America, recent studies with state secondary school learners (Banegas \& Lauze, 2020; Garzón-Díaz, in press) have provided evidence that CLIL, when it includes systematic language support and translingual practices, allows learners with an A2 (CEFR) level of English to acquire subject knowledge and develop their academic L2 proficiency. While these two studies are promising, further research is needed to examine what pedagogical strategies can succeed in extending CLIL to contexts such as state schools, where English provision may be limited compared to private bilingual schools (Yilorm Barrientos \& Acosta Morales, 2016; Pimentel Siqueira et al., 2018).

In a recent study conducted in Brazil, Landau, Albuquerque Paraná, and Siqueira (in press) investigated how CLIL has led to the emergence of 'a local stakeholder self-titled as Sistemas Educacionais' (p. x) [educational systems], i.e., business that operate in the private bilingual education sector in Brazil and provide them with 'solutions' to their educational needs. In this context, CLIL is marketed as an approach that will help learners secure global mobility, fluency, access to exclusive social practices, and superiority in terms of educational experience. The authors conclude that CLIL is not only franchised as an exclusive approach only available to the dominant classes in Brazil, but also as a means to perpetuate colonial mechanisms through which 'foreigners' aspire to belong to English-speaking societies and what they represent. Hence, further research is needed to understand whether CLIL may (inadvertently) become a new site for social inclusion/exclusion or an obstacle to decolonise the L2 curriculum.

\section{Conclusion}

The purpose of this paper was to review and reflect on CLIL research and practice in South America around three relationships: (1) research with successful results, (2) research with mixed results, and (3) research yet to be carried out. Through these three relationships my intention is to foster dialogue, thinking, and informed action among those who wish to improve CLIL provision not only in South America but also elsewhere.

Although this paper has been limited to one vast geographical region of the world and biased due to my personal interests and experiences but mostly based on published and accessible articles, it may offer some insights about future directions. Regarding research implications, CLIL research and practice should be fostered in such a way that stronger and sustainable synergy is achieved between both. On the one hand, the CLIL community in South America may wish to maximise experiences and research outcomes. On the other hand, the issues raised on research not well applied or yet to be welcome may become an opportunity for extending the frontiers of CLIL research and practice and perhaps put forward indigenous models of integrating content and language learning for/from South America which may inform practices far and wide. In addition, this might be a fruitful opportunity to engage in collaborative research and pedagogical undertakings across the region and with CLIL colleagues established elsewhere.

\section{References}

Acosta, H., \& Yilorm, Y. (2016). El proceso de enseñanza aprendizaje de la lengua inglesa bajo el enfoque focal skills en escuelas públicas. Atenas, 33, 40-50.

Airey, J. (2016). EAP, EMI or CLIL? In K. Hyland, \& P. Shaw (Eds.), The Routledge handbook of English for academic purposes. London, UK: Routledge.

Alonso-Belmonte, I., \& Fernández-Agüero, M. (2018). The C of cognition in CLIL teacher education: Some insights from classroom-based research. In Y. Kırkgöz \& K. Dikilitaş (Eds.), Key issues in English for Specific Purposes in higher education (pp. 305-322). Cham, Switzerland: Springer. 
Amado Valdivia, A. (2012). The design of content \& language integrated learning (CLIL) course for the interwoven development of content, communication, cognition \& culture (Unpublished master's dissertation). Universidad de Piura, Peru.

Amaral, O., Garrison, L., \& Klentschy, M. (2002). Helping English learners increase achievement through inquiry-based science instruction. Bilingual Research Journal, 26(2), 213-239.

Anderson, C. E. (2011). CLIL for CALP in the multilingual, pluricultural, globalized knowledge society: Experiences and backgrounds to L2 English usage among Latin American L1 Spanish users. Latin American Journal of Content \& Language Integrated Learning, 4(2), 51-66.

Anderson, C. E., Mora González, C. A., \& Cuesta Medina, L. M. (2018). Graphic organizers support young L2 writers' argumentative skills. GIST - Education and Learning Research Journal, 17, 6-33.

Argudo, J., Abad, M., Fajardo-Dack, T., \& Cabrera, P. (2018). Analyzing a pre-service EFL program through the lenses of the CLIL approach at the University of Cuenca-Ecuador. Latin American Journal of Content and Language Integrated Learning, 11(1), 65-86.

Ball, P. (2018). Innovations and challenges in CLIL materials design. Theory Into Practice, 57(3), 222-231.

Ball, P., Kelly, K., \& Clegg, J. (2015). Putting CLIL into practice. Oxford, UK: Oxford University Press.

Banegas, D. L. (2013). The integration of content and language as a driving force in the EFL lesson. In E. Ushioda (Ed.), International perspectives on motivation: Language learning and professional challenges (pp. 82-97). Basingstoke, UK: Palgrave.

Banegas, D. L. (2016). Teachers develop CLIL materials in Argentina: A workshop experience. Latin American Journal of Content and Language Integrated Learning, 9(1), 17-36.

Banegas, D. L. (2017). Teacher-developed materials for CLIL: Frameworks, sources, and activities. Asian EFL Journal, 19(3), 31-48.

Banegas, D. L. (2018). Learning subject-specific content through ESP in a Geography-teaching programme: An action research story in Argentina. English for Specific Purposes, 50(1), 1-13.

Banegas, D. L., Corrales, K., \& Poole, P. (2020). Can engaging L2 teachers as material designers contribute to their professional development? Findings from Colombia. System, 91, https://doi.org/10.1016/j.system.2020.102265

Banegas, D. L., \& del Pozo Beamud, M. (2020). Content and language integrated learning: A duoethnographic study about CLIL pre-service teacher education in Argentina and Spain. RELC Journal. https://doi.org/10.1177/0033688220930442

Banegas, D. L., \& Lauze, C. (2020). CLIL and comprehensive sexual education: A case of innovation from Argentina. Profile, 22(2), 199-209.

Banegas, D. L., Poole, P., \& Corrales, K. (2020). Content and language integrated learning in Latin America 2008-2018: Ten years of research and practice. Studies in Second Language Learning \& Teaching, 10(2), 283-305.

Barahona, M., \& Benítez, R. (2020). Empowering Chilean student-teachers to become highly capable English language educators. In D. L. Banegas (Ed.), Content knowledge in English language teacher education: International experiences (pp. 185-200). London, UK/New York, NY: Routledge.

Bower, K., Coyle, D., Cross, R., \& Chambers, G. N. (Eds.). (2020). Curriculum integrated language teaching: CLIL in practice. Cambridge, UK: Cambridge University Press.

Bruton, A. (2019). Questions about CLIL which are unfortunately still not outdated: A reply to Pérez-Cañado. Applied Linguistics Review, 10(4), 591-602.

Casal Madinabeitia, S. (2007). The integrated curriculum, CLIL and constructivism. Revista Española de Lingüística Aplicada, 1, 55-66.

Castellani, E., Dabove, C., \& Colucci, L. (2009). Teaching EFL or teaching art? In D. Fernández (Ed.), XXXIV FAAPI conference proceedings: Teachers in action (pp. 272-275). Bahía Blanca, Argentina: FAAPI.

Cendoya, A. M., \& Di Bin, M. V. (2010). A CLIL experience based on the use of tasks and different genre types. Latin American Journal of Content \& Language Integrated Learning, 3(1), 11-17.

Cenoz, J. (2015). Content-based instruction and content and language integrated learning: the same or different? Language, Culture and Curriculum, 28(1), 8-24.

Cossu, P., Brun, G., \& Banegas, D. L. (2021). Supporting in-service teachers for embracing comprehensive sexual education in the ELT classroom. In D. Banegas, M. Pérez Berbain, \& G. Beacon (Eds.), International perspectives on diversity in ELT (pp. 220-242). Basingstoke, UK: Palgrave.

Council of Europe. (2016). Competences for democratic culture. Living together as equals in culturally diverse democratic societies. Strasbourg, France: Council of Europe.

Coyle, D. (2007). Content and language integrated learning: Towards a connected research agenda for CLIL pedagogies. International Journal of Bilingual Education and Bilingualism, 10(5), 543-562.

Coyle, D., Hood, P., \& Marsh, D. (2010). CLIL: Content and language integrated learning. Cambridge: Cambridge University Press.

Dalton-Puffer, C., Llinares, A., Lorenzo, F., \& Nikula, T. (2014). 'You can stand under my umbrella': Immersion, CLIL and bilingual education. A response to Cenoz, Genesee, \& Gorter (2013). Applied Linguistics, 35(2), 213-218.

De la Barra, E., Veloso, S., \& Maluenda, L. (2018). Integrating assessment in a CLIL-based approach for second-year university students. Profile: Issues in Teachers' Professional Development, 20(2), 111-126. 
Doiz, A., Lasagabaster, D., \& Sierra, J. M. (2014). CLIL and motivation: The effect of individual and contextual variables. Language Learning Journal, 42(2), 209-224.

European Commission. (1995). Teaching and learning: Towards the learning society. White paper on education and training. COM (95) 590. Brussels.

Eurydice. (2006). Content and language integrated learning (CLIL) at school in Europe. Brussels, Belgium: European Commission.

Fazzi, F., \& Lasagabaster, D. (2020). Learning beyond the classroom: students' attitudes towards the integration of CLIL and museum-based pedagogies. Innovation in Language Learning and Teaching, doi:10.1080/17501229.2020.1714630

Fernández, D. (Ed.). (2008). Using the language to learn and learning to use the language: What's next in Latin America. XXXIII FAAPI Conference Proceedings. Santiago del Estero, Argentina: FAAPI.

Fernández-Agüero, M., \& Chancay-Cedeño, C. (2019). Interculturality in the language class: Teachers' intercultural practices in Ecuador. RELC Journal, 50(1), 164-178.

Finardi, K. R., Silveira, N., Lima, S., \& Mendes, A. (2016). MOOC in the inverted CLIL approach: Hybridizing English teaching/learning. Studies in English Language Teaching, 4, 473-493.

Gallardo del Puerto, F., Basterrechea, M., \& Martínez Adrián, M. (2019). Target language proficiency and reported use of compensatory strategies by young CLIL learners. International Journal of Applied Linguistics, doi.org/10.1111/ijal.12252

García, O., \& Lin, A. (2017). Translanguaging in bilingual education. In O. García (Ed.), Bilingual and multilingual education (pp. 117-130). New York, NY: Springer.

Garzón-Díaz, E. (2018). From cultural awareness to scientific citizenship: Implementing content and language integrated learning projects to connect environmental science and English in a state school in Colombia. International Journal of Bilingual Education and Bilingualism, doi:10.1080/13670050.2018.1456512

Garzón-Díaz, E. (in press). Translanguaging in science lessons: Exploring the language of science in L2 low achievers in a public school setting in Colombia. In C. Hemmi \& D. L. Banegas (Eds.), International perspectives on CLIL. Cham, Switzerland: Palgrave.

Glyn Lewis, E. (1976). Bilingualism and bilingual education: The ancient world to the renaissance. In J. Fishman (Ed.), Bilingual education: An international sociological perspective (pp. 151-200). Rowley, MA: Newbury House.

Goris, J., Denessen, E., \& Verhoeven, L. (2019). The contribution of CLIL to learners' international orientation and EFL confidence. Language Learning Journal, 47(2), 246-256.

Helver, A. (2015). The plurilingual classroom and ELT: The challenge to overcome tensions between aboriginal languages and hegemonic languages. Argentinian Journal of Applied Linguistics, 3(2), 67-78.

Hemmi, C., \& Banegas, D. L. (Eds.). (2021). International perspectives on CLIL. Cham, Switzerland: Palgrave.

Keogh, C. (2017). Using WhatsApp to create a space of language and content for students of international relations. Latin American Journal of Content and Language Integrated Learning, 10(1), 75-104.

Lamb, M., Csizér, K., Henry, A., \& Ryan, S. (Eds.). (2019). The Palgrave handbook of motivation for language learning. Cham, Switzerland: Palgrave.

Landau, J., Albuquerque Paraná, R., \& Siqueira, S. (in press). Sistemas Educacionais (SE) and CLIL developments in Brazil: From promises to prospects. In C. Hemmi \& D. L. Banegas (Eds.), International perspectives on CLIL. Cham, Switzerland: Palgrave.

Lasagabaster, D. (2011). English achievement and student motivation in CLIL and EFL settings. Innovation in Language Learning and Teaching, 5(1), 3-18.

Lasagabaster, D. (2019). Motivation in content and language integrated learning (CLIL) research. In M. Lamb (Ed.), The Palgrave handbook of motivation for language learning (pp. 347-366). Cham, Switzerland: Palgrave.

Lasagabaster, D., \& Doiz, A. (2017). A longitudinal study on the impact of CLIL on affective factors. Applied Linguistics, $38(5), 688-712$.

Lasagabaster, D., Doiz, A., \& Sierra, J. M. (Eds.). (2014). Motivation and foreign language learning: From theory to practice. Amsterdam, Netherlands: John Benjamins.

Leat, D. (Ed.). (2017). Enquiry and project based learning. Abingdon, UK/New York, NY: Routledge.

Leaver, B. L., \& Stryker, S. B. (1989). Content-Based instruction for foreign language classrooms. Foreign Language Annals, 22(3), 269-275.

Lightbown, P. (2014). Focus on content-based language teaching. Oxford, UK: Oxford University Press.

Lightbown, P., \& Spada, N. (2019). Teaching and learning L2 in the classroom: It's about time. Language Teaching, doi:10.1017/S0261444819000454

Lin, A. M. Y. (2015). Conceptualising the potential role of L1 in CLIL. Language, Culture and Curriculum, 28(1), 74-89.

Llinares, A., \& Morton, T. (Eds.) (2017). Applied linguistics perspectives on CLIL. Amsterdam, Netherlands: John Benjamins.

Llinares, A., Morton, T., \& Whittaker, R. (2012). The roles of language in CLIL. Cambridge, UK: Cambridge University Press.

Lorenzo, F. (2008). Instructional discourse in bilingual settings: an empirical study of linguistic adjustments in content and language integrated learning. Language Learning Journal, 36(1), 21-33.

Lyster, R. (2007). Learning and teaching languages through content: A counterbalanced approach. Amsterdam, Netherlands: John Benjamins. 
Macaro, E., Curle, S., Pun, J., An, J., \& Dearden, J. (2018). A systematic review of English medium instruction in higher education. Language Teaching, 51(1), 36-76.

Mahan, K. R. (2020). The comprehending teacher: Scaffolding in content and language integrated learning (CLIL). Language Learning Journal, doi:10.1080/09571736.2019.1705879

Mariño Avila, C. M. (2014). Towards implementing CLIL at CBS (Tunja, Colombia). Colombian Applied Linguistics Journal, 16(2), 151-160.

Marsh, D. (Ed.). (2002). CLIL/EMILE - The European dimension: Actions, trends and foresight potential public services. European Commission.

Marsh, D., \& Langé, G. (Ed.). (1999). Implementing content and language integrated learning: A research-driven foundation course reader. Milan, Italy/Jyväskylä, Finland: University of Jyväskylä.

Marsh, D., \& Nikula, T. (1998). Terminological considerations regarding content and Language integrated learning. Neuchatal, Switzerland: Bulletin Suisse de Linguistique Appliquee.

Marsh, D., \& Wolff, D. (Eds.). (2007). Diverse contexts - converging goals: CLIL in Europe. Frankfurt, Germany: Peter Lang.

McDougald, J. (2015). Teachers' attitudes, perceptions and experiences in CLIL: A look at content and language. Colombian Applied Linguistics Journal, 17(1), 25-41.

McDougald, J., \& Pissarello, D. (2020). Content and language integrated learning: In-service teachers' knowledge and perceptions before and after a professional development program. Íkala, Revista de Lenguaje y Cultura, 25(2), 353-372.

Megale, A. H., \& Coelho Liberali, F. C. (2016). Caminhos da educação bilíngue no Brasil: Perspectivas da linguística aplicada. Raído, 10(1), 9-24.

Mehisto, P. (2012). Criteria for producing CLIL learning material. Encuentro, 21, 15-33.

Méndez García, M. (2012). The potential of CLIL for intercultural development: A case study of Andalusian bilingual schools. Language and Intercultural Communication, 12(3), 196-213.

Moore, P., \& Lorenzo, F. (2015). Task-based learning and content and language integrated learning materials design: Process and product. Language Learning Journal, 43(3), 334-357.

Nikula, T., Dafouz, E., Moore, P., \& Smit, U. (Eds.). (2016). Conceptualising integration in CLIL and multilingual education. Bristol, UK: Multilingual Matters.

Nikula, T., \& Moore, P. (2019). Exploring translanguaging in CLIL. International Journal of Bilingual Education and Bilingualism, 22(2), 237-249.

Paran, A. (2013). Content and language integrated learning: Panacea or policy borrowing myth? Applied Linguistics Review, 4(2), 317-342.

Pavón Vázquez, V. (2018). Innovations and challenges in CLIL research: Exploring the development of subject-specific literacies. Theory into Practice, 57(3), 204-211.

Pérez-Cañado, M. L. (2012). CLIL research in Europe: Past, present, and future. International Journal of Bilingual Education and Bilingualism, 15(3), 315-341.

Pérez Cañado, M. L. (2016). Are teachers ready for CLIL? Evidence from a European study. European Journal of Teacher Education, 39(2), 202-221.

Pimentel Siqueira, D. S., Landau, J., \& Albuquerque Paraná, R. (2018). Innovations and challenges in CLIL implementation in South America. Theory into Practice, 57(3), 196-203.

Pinner, R. S. (2013). Authenticity and CLIL: Examining authenticity from an international CLIL perspective. International CLIL Research Journal, 2, 44-54.

Pinner, R. S. (2019). Authenticity and teacher-student motivational synergy: A narrative of language teaching. London, UK/ New York, NY: Routledge.

Porto, M. (2016). Ecological and intercultural citizenship in the primary English as a foreign language (EFL) classroom: An online project in Argentina. Cambridge Journal of Education, 46(4), 395-415.

Porto, M. (2018). Intercultural citizenship in foreign language education: An opportunity to broaden CLIL's theoretical outlook and pedagogy. International Journal of Bilingual Education and Bilingualism. https://doi.org/10.1080/13670050.2018. 1526886

Roiha, A., \& Sommier, M. (2018). Viewing CLIL through the eyes of former pupils: Insights into foreign language and intercultural attitudes. Language and Intercultural Communication, 18(6), 631-647.

Rodas, F. D., \& Santillán, J. J. (2018). Understanding multilingualism and interculturalism from an Ecuadorian perspective. Argentinian Journal of Applied Linguistics, 6(2), 42-52.

Rodriguez Bonces, M. (2011). CLIL: Colombia leading into content language learning. Ikala, 16(2), 79-89.

Ruiz de Zarobe, Y. (2015). Language awareness and CLIL. In J. Cenoz, D. Gorter, \& S. May (Eds.), Language awareness and multilingualism. Encyclopedia of language and education (3rd ed.). Cham, Switzerland: Springer.

Torres-Rincón, J. C., \& Cuesta-Medina, L. M. (2019). Situated practice in CLIL: Voices from Colombian teachers. GIST Education and Learning Research Journal, 18, 109-141.

Tsuchiya, K., \& Pérez Murillo, M. D. (Eds.). (2019). Content and language integrated learning in Spanish and Japanese contexts: Policy, practice and pedagogy. Basingstoke, UK: Palgrave.

Uribe-Enciso, O., Uribe-Enciso, D., \& Vargas-Daza, M. (2017). Critical thinking and its importance in education: Some reflections. Rastros Rostros, 19, 78-88. 
Ushioda, E. (2016). Language learning motivation through a small lens: A research agenda. Language Teaching, 49(4), 564-577.

Valeo, A. (2013). Language awareness in a content-based language programme. Language Awareness, 22(2), $126-145$.

van Kampen, E., Meirink, J., Admiraal, W., \& Berry, A. (2017). Do we all share the same goals for content and language integrated learning (CLIL)? Specialist and practitioner perceptions of 'ideal' CLIL pedagogies in the Netherlands. International Journal of Bilingual Education and Bilingualism, doi:10.1080/13670050.2017.1411332

Vega, M., \& Moscoso, M. L. (2019). Challenges in the Implementation of CLIL in higher education: From ESP to CLIL in the tourism classroom. Latin American Journal of Content \& Language Integrated Learning, 12(1), 144-176.

Yilorm Barrientos, Y., \& Acosta Morales, H. (2016). Neoliberalismo y proceso de enseñanza-aprendizaje de la lengua inglesa en Chile: Una mirada dialéctica al estado del arte en sectores vulnerables. Revista Cubana de Educación Superior, 35(3), 125-136.

Zhyrun, I. (2016). Culture through comparison: Creating audio-visual listening materials for a CLIL course. Latin American Journal of Content and Language Integrated Learning, 9(2), 345-373.

Darío Luis Banegas is a Lecturer in TESOL at the University of Strathclyde (UK) and an Associate Fellow with the University of Warwick (UK). In Argentina, Darío leads online pre-service teacher education modules on English language teaching methodologies and teacher research. His main pedagogical and research interests are: CLIL, pre-service language teacher education, action research, and English Language Teaching knowledge flow in/from Latin America.

Cite this article: Banegas, D. L. (2022). Research into practice: CLIL in South America. Language Teaching, 55(3), 379-391. https://doi.org/10.1017/S0261444820000622 